
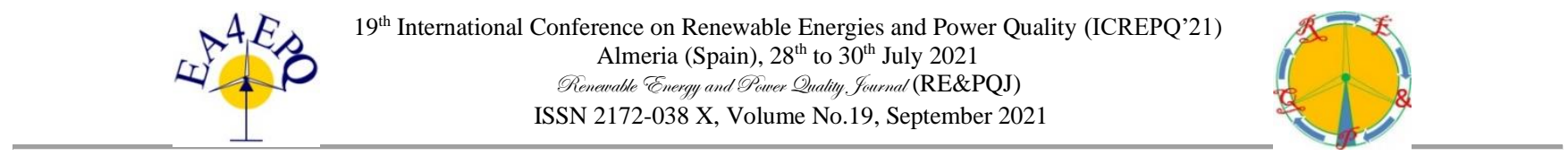

\title{
Solar Carport
}

Dr. Péter Kádár ${ }^{1}$, senior member of IEEE; Dr. Robert Istók ${ }^{1}$; Levente Reizer ${ }^{2}$

\author{
${ }^{1}$ Óbuda University \\ Dept. of Power Systems, Alternative Energy Sources Knowledge Centre \\ Bécsi u. 94. Budapest H-1034 HUNGARY
}

Phone: +36 209447 241; e-mail: kadar.peter@kvk.uni-obuda.hu; istok.robert@kvk.uni-obuda.hu

\author{
2 Premium Napelem Kft \\ Selyemfonó utca 6. Budapest H-1033 HUNGARY \\ e-mail: reizer.levente@premiumnapelem.hu
}

\begin{abstract}
A Solar Carport integrated with second-life EV batteries was installed at Óbuda University. It collects and stores solar energy and charges electric vehicles. It is a fully green concept, not just because of the solar panels or EV charging, but it is giving a 2nd life to electric vehicle batteries that are produced in a huge amount for the automotive market and ready to be utilized for green energy storage. The system demonstrates how an average household can combine the second-life EV batteries with a solar system and charger.

The system consists of Solar panels, Inverter, EV batteries, EV chargers and Battery Management Unit (BMS). The remotely controlled element of the Solar Carport can be a detail of the city-wide microgrid too.
\end{abstract}

Keywords. Solar Carport, EV Batteries as storage, PV, EV charger.

\section{Introduction}

The number of the EV's is strongly increasing by any forecast (see Fig.1.). One of the main elements of an EV is the battery. The EV batteries span from $20 \mathrm{kWh}$ up to 200 $\mathrm{kWh}$ [1]. So 10 million $100 \mathrm{kWh}$ EV cars require 1000 GWh battery capacity.

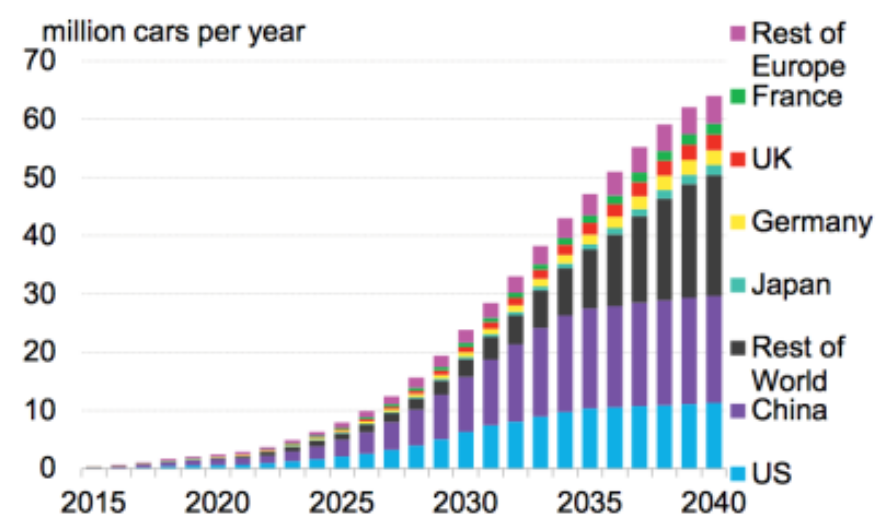

Fig. 1. Annual global EV sales by market [2]
The future lithium-ion battery need is shown in Fig.2. Let us mention that now "we are" in the figure, the first five years are facts. The world's lithium-ion battery production was about $345 \mathrm{GWh}$ in 2020 [3].

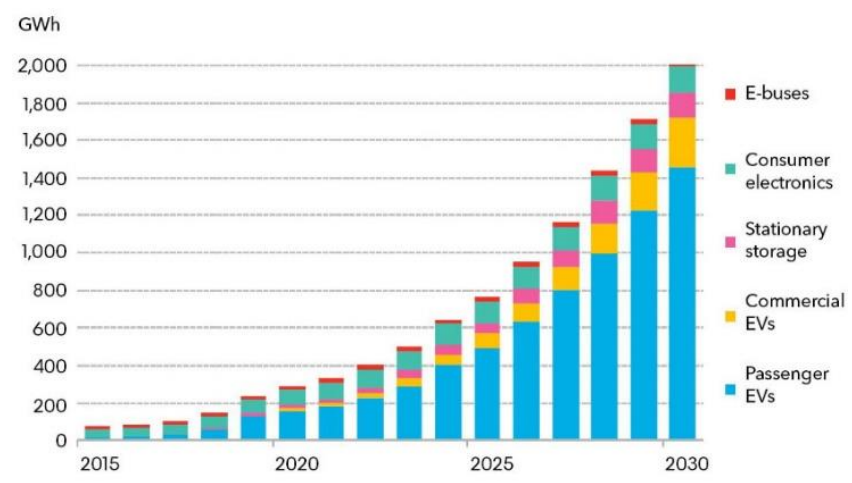

Fig. 2. Forecast of annual lithium-ion battery demand [4]

In spite of the high expectations the lifetime of the batteries is limited and strongly depends on the usage of the EV. It is hard to find an EV with 10 years old batteries. The batteries are working but with limited characteristics (see Fig.3.).

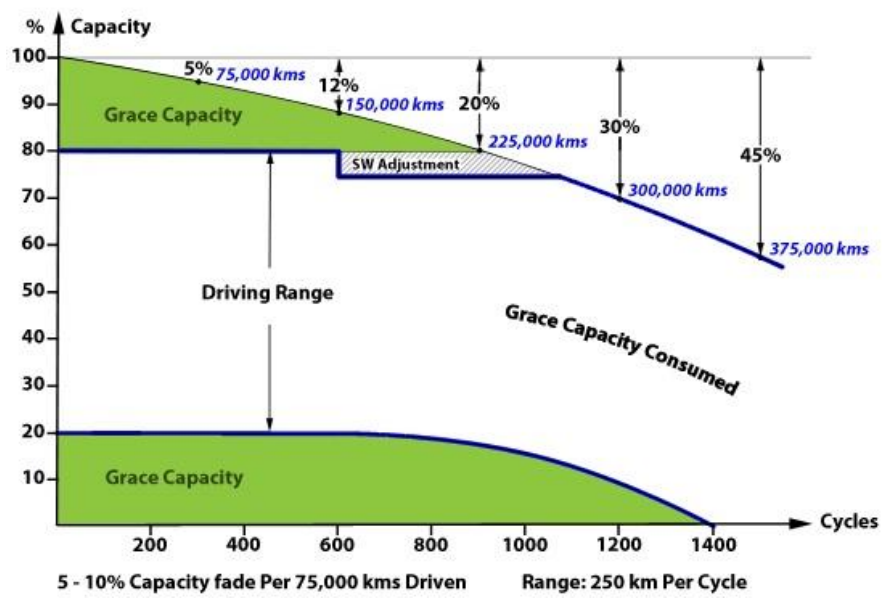

Fig. 3. Aging of batteries by usage [5] 
After 10 years the battery becomes waste. That can be deposited or recycled. The energy invested by the battery production won't be utilized any further.

Meanwhile, in another market, the power storage need is growing. It has two directions as the concentrated high dynamic power system inertia and FACT tools and the distributed low capacity (5-30 kWh), low dynamic household storages. It is estimated to reach $305 \mathrm{Gwh}$ by 2030 (see Fig.4.).

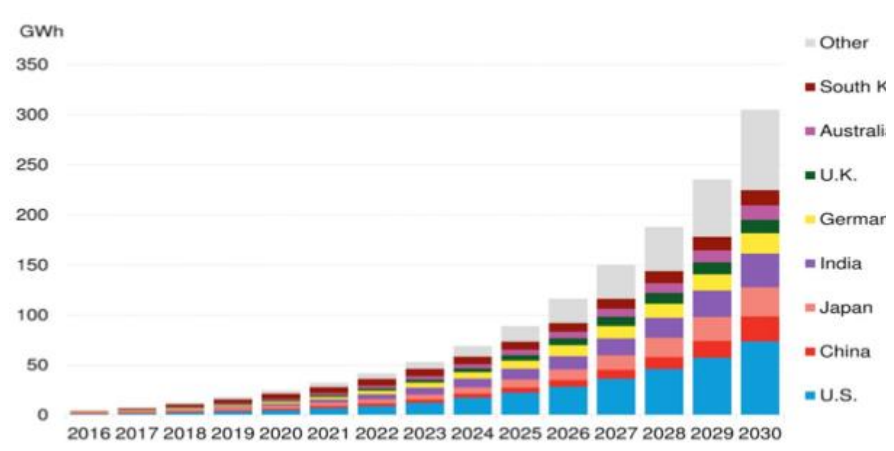

Fig. 4. Forecast of global storage capacity forecast [6]

The specific European household storage deployment is shown in Fig.5. It is roughly $1 \%$ of the total storage need but a well isolable group of application.

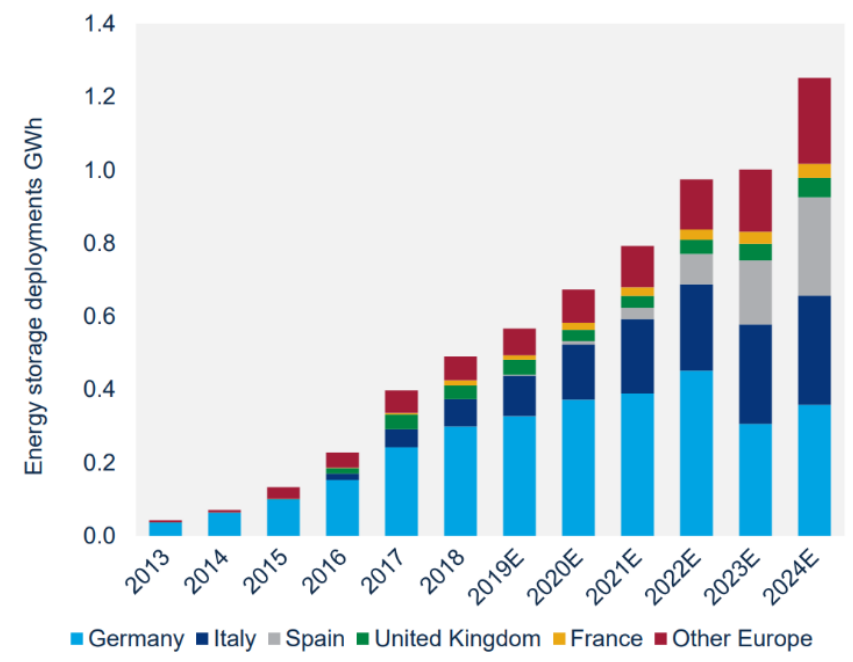

Fig. 5. The annual Europe residential storage deployments [7]

If we match the storage need with the emerging secondhand EV batteries we gain a lot of energy and material. It helps sustainability and saves the environment.

\section{The environmental effects}

All human activities have environmental impacts. The effects are mainly negative such as the exhaust of the materials, waste depository, $\mathrm{CO}_{2}$ emission, energy usage... By the Life Cycle Assessment methodology [17], the environmental load can be calculated for all steps of the EV battery process such as mining, transportation, drying, coating, filling, packing, welding, etc. The many diverse affections are condensed in the specific equivalent numbers as all the greenhouse gases are going to $\mathrm{CO}_{2}$ equivalent and all the acidic emission goes to the $\mathrm{SO}_{2}$ equivalent. This $\mathrm{CO}_{2}$ footprint can be projected in per $\mathrm{km}$ unit (see Fig. 6.).

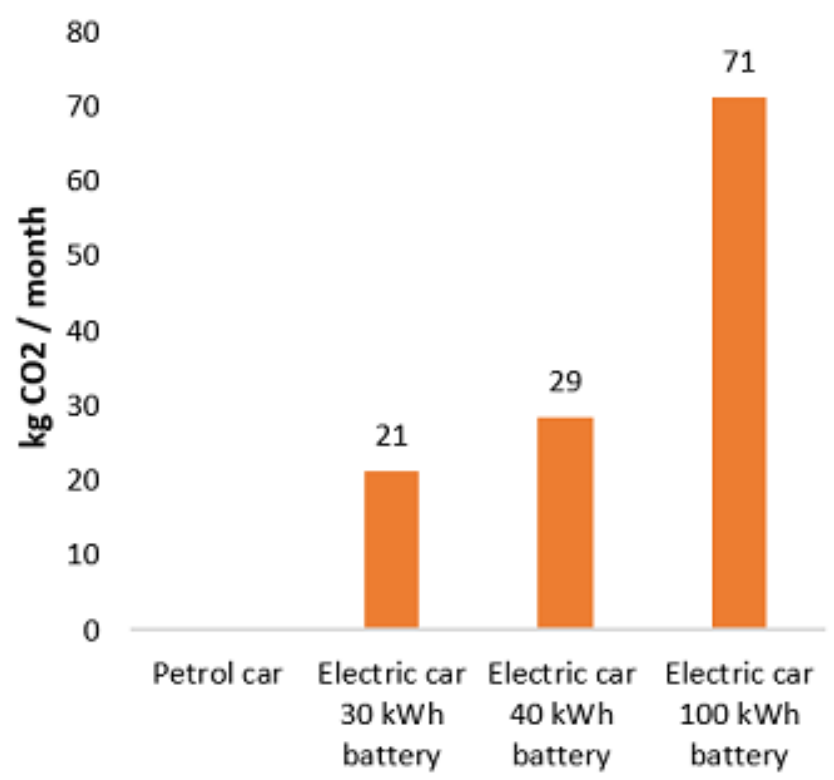

Fig. 6. $\mathrm{CO}_{2}$ footprint of battery production [8]

The battery production of the EV requires so much energy and produce so much $\mathrm{CO}_{2}$ like the production of the car chassis [9]. Moreover, this energy and emission are doubled if we produce a brand new battery explicitly for storage purposes.

We aim to double the useful lifetime of the EV batteries with the extension of the usage period in a quiet household storage mode.

But how can we put it into action in our close ambiance?

\section{The novel application}

In this innovative development we applied the following elements:

- the PV (photovoltaic) generation is known for decades it is widely spread over -> PV

- the household battery systems are used for the intraday storage of PV energy -> storage

- It is useful if the parking lot (carport) is shielded against the strong solar irradiation for extending the lifetime of the car and to decrease the air conditioning energy need -> shadowing

- thousands of new electric cars are coming into service today but these will leave millions of battery units that must be treated -> used battery

- the slow and medium speed (3-22 kW) EV chargers typically work at night when the car owner arrives at home -> EV charger

- instead of serially connected high voltage battery systems we put parallel the $48 \mathrm{~V}$ DC packs 


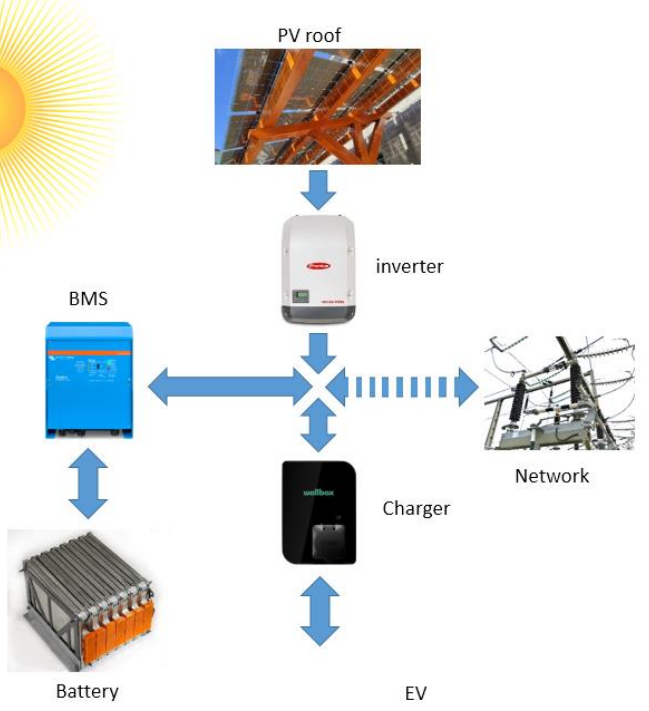

Fig. 7. The Solar Carport System

\section{The system}

The Solar Carport demonstrational unit includes the followings (see Fig.8.):

- 7 kW Glass-Glass, high-quality solar panels

- $\quad 7 \mathrm{~kW}$ Fronius inverter with smart meter and remote control functionality

- 2 units of $22 \mathrm{~kW}$ Wallbox Copper SB smart charger with remote control functionality

- 2 units of flexible Victron Battery Management System with remote control functionality

- $\quad 2$ units of Nissan LEAF $2^{\text {nd }}$ life batteries, some of the battery modules

- A wooden (green message) strong (laminated technology) stand, designed for this purpose

- The full system can be remotely monitored and controlled

- Every single component of the system is produced in Europe (including the EV battery)

\section{A. The roof}

The Solar Carport is a roof holder structure made of cemented layer wooden parts with 3 legs. It covers/shadows twin EV charging park slots. The PV panels are on the roof. The chargers are fixed on the legs and the other electronic parts as the inverter, batteries and battery management system are put in a steel box close to the roof.

\section{B. The PV panels}

We applied monocrystalline double glass semi-transparent PV panels, a product of Soli Tek company, Lithuania. The 24 pcs of $320 \mathrm{~W}_{\mathrm{p}}$ panels provides $7,680 \mathrm{~W}_{\mathrm{p}}$. The highquality panels have 30 years $90 \%$ capacity guarantee.

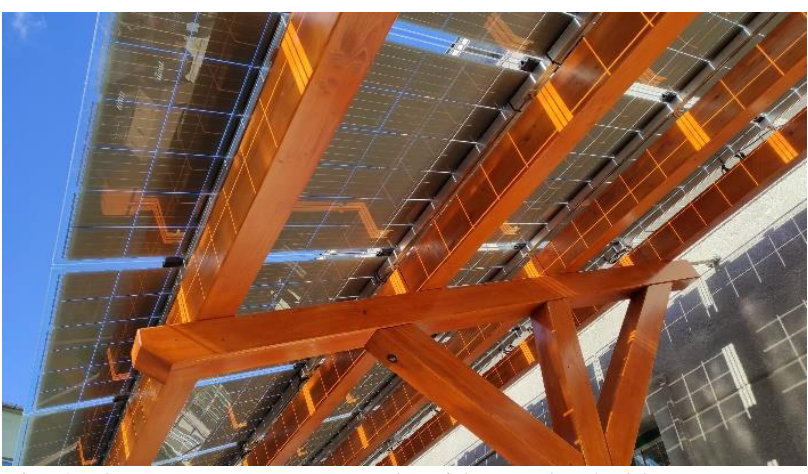

Fig. 8 The transparent PV panels with wooden holders

\section{The charger}

The system is mounted with 2 pcs of Wallbox Copper $\mathrm{S}$ AC charger with Charge Mode 3. / Connector Type2. It has built-in DC fault identification. It can be remotely controlled (web access) and also integrated with an RFID key card.

\section{The inverter}

The elements of the system are connected to a one-phase $230 \mathrm{VAC}$ bus. The PV generation flows through an $8,2 \mathrm{~kW}$ Fronius Inverter. We built in a Fronius Smart Meter that is capable of load control till 63 A, data log, load optimization, web access and visualization.

\section{E. Batteries}

We built in 4 - 8-year-old Nissan Leaf Lithium-Ion LiMn2O4/LiNiO2 battery modules. The early Nissan LEAF in 2012 contained a $24 \mathrm{kWh}$ capacity battery -24 modules, 4-cells / module, $0.25 \mathrm{kWh} /$ cell. The 2018 LEAF has already $40 \mathrm{kWh}$ capacity in 24 modules, 8 -cells / module, $0.21 \mathrm{kWh} /$ cell.

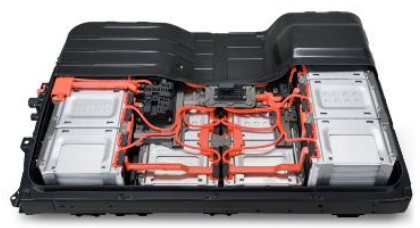

$62 \mathrm{kWh}$

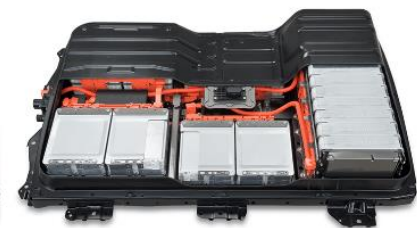

40 kWh
Fig. 9. Compact EV battery packs [10]

\section{F. Battery Management System}

The Battery Management System (BMS - Victron Energy Quattro 48V 8KW inverter/charger manages the battery depending on the SOC (State of Charge). It is possible to remotely control through Web access (Victron Color Control GX). Although in the normal operation in the EV the typical voltage level is $400 \mathrm{~V}$ od above, in the secondhand mode we connected $48 \mathrm{~V}$ battery packs parallel. The BMS also includes integrated protection from sc., overload, overheating, deep discharge, overcharge, and other irregularities. 


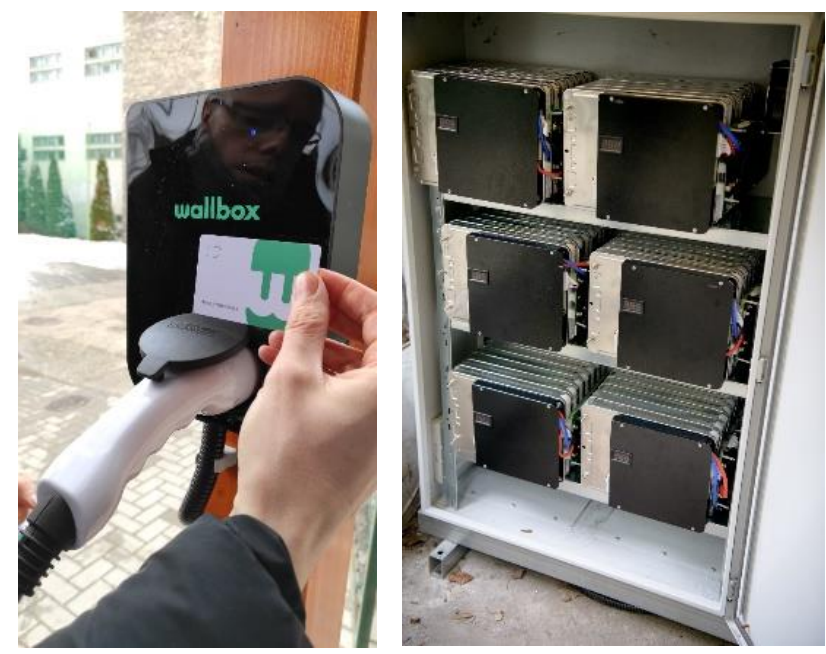

Fig. 10. The Charger with RFID card and the EV batteries

\section{G. Protections}

The system contains various protections:

Electric Shock protection

- DC side double insulation

- $\quad$ AC side TN-S system

- In the inverter integrated Residual Current Device $=\mathrm{RCD}$

Overvoltage

- DC side T2 overvoltage protection

- $\quad$ AC side Noark Ex9UE2 20, T2 surge protection

Overcurrent

- $\quad$ DC side 16 A fuse

- AC side overcurrent 3x16A breaker

For cabling, we applied at DC lines $4 \mathrm{~mm}^{2} \mathrm{UV}$ resistant solar cables and at the AC lines $1000 \mathrm{~V} 5 \times 6 \mathrm{~mm}^{2}$ FG16OR16 cable.

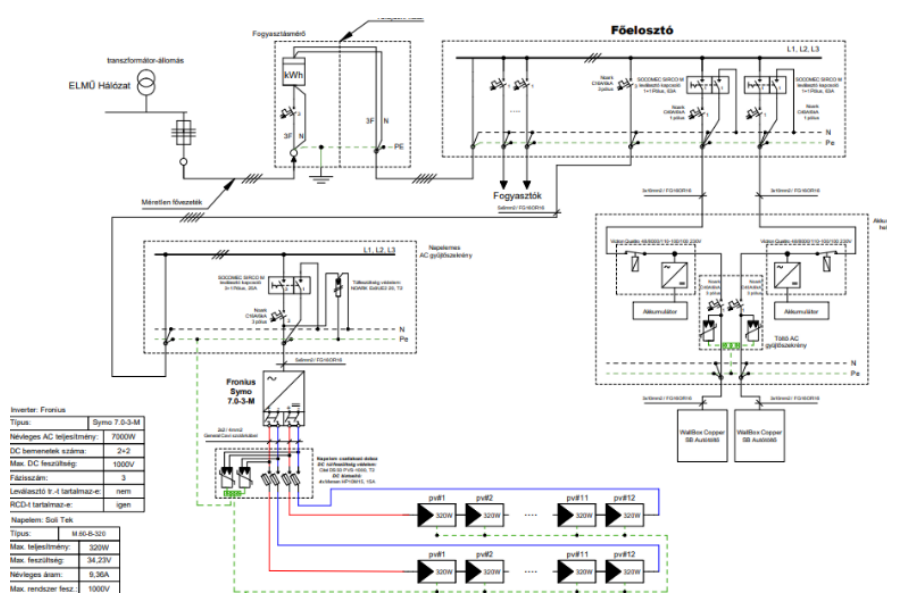

Fig. 11. The general scheme

\section{H. Operational modes}

The following operational modes can be tested

- PV generation directly to EV charger

- PV generation to Battery

- PV generation to the network

- Battery discharge to EV charger (Island mode operation)

- $\quad$ Network supply to EV charger
- In the future, the system will be extended by V2G (Vehicle-to-grid) capacity when the EV can inject energy into the grid

\section{Scalable solution}

At the application site, the annual irradiation is approx. $1200 \mathrm{kWh} / \mathrm{m} 2$. The yearly energy yield is about $1240 \mathrm{kWh}$ / $\mathrm{kWp}$. In this manner, the average energy yield is about $27 \mathrm{kWh}$ by the $8 \mathrm{~kW}$ system (of course it depends on the season and the weather). The average consumption by an $\mathrm{EV}$ is $0,15 \mathrm{kWh} / \mathrm{km}$, so the daily solar energy is enough for a $180 \mathrm{~km}$ daily run for EVs. We started with a 6 x 1,1 $\mathrm{kWh}$ battery pack that stores only a quarter of the daily solar production.

The demonstration application system is scalable by the extension of the storage capacity and also by the number of the PV panels. We may store energy for more days and more cars. We use for storage the power network (feed in the surplus).

\section{Multipurpose application}

With this demonstrational system

- we gave a second life to the used EV batteries

- the students can practice the PV system sizing

- with this application, we realized a dream/plan that was published an 8 years ago [11]

- we can teach energy consciousness and we show a more sustainable solution

- $\quad$ further PV panel characteristics, tests and measurements can be continued [12-16]

- we can plan and simulate larger-scale solutions with more charger, more battery and PV capacity

- $\quad$ this is a testbed for island mode operation and later for the $2 \mathrm{G}$ test

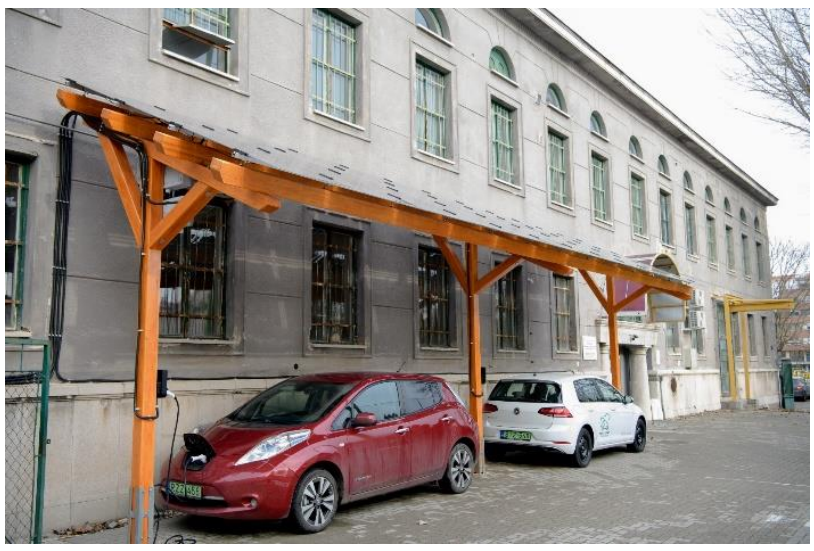

Fig. 12. The Solar Carport

\section{Conclusion}

In the yard of the Óbuda University, we realized an innovative solar carport that includes second-life EV batteries, double glass PV panels and EV chargers. It is a recommendation to realize hundreds of similar and largerscale systems for a more sustainable future. 


\section{Acknowledgement}

The authors thank the support of EIT Urban Mobility Mobility for more liveable urban spaces (eiturbanmobility.eu), making possible this development. Also, many thanks to Nissan Hungary for providing the LEAF battery modules.

The Solar Carport is also a demonstrational application of the European Climate Initiative (EUKI) project No. 81263388 funded by German Federal Ministry for Environment, Nature Conservation and Nuclear Safety. The objective of the project is to breake barriers to low carbon investment in Budapest. In partnership with Budapest Municipality and Association for Solar Energy the Óbuda University works on „How to install more PV on the roof of Budapest buildings?" Solar carport is one of the typified solutions that recommended for small households and also for public parking lots ( $\mathrm{n} \times 5 \mathrm{~kW})$.

\section{References}

[1] https://www.myev.com/research/ev-101/electric-vehicle-batterybasics

[2] Bloomberg New Energy Finance https://www.greencarcongress.com/2017/07/20170706-bnef.html

[3] Global lithium-ion cell manufacturing capacity to quadruple to 1.3 TWh by 2030 - Leader China to double pipeline capacity by 2030 ; 11 August 2020, https://www.woodmac.com/press-releases/globallithium-ion-cell-manufacturing-capacity-to-quadruple-to-1.3-twhby-2030/4

[4] World Battery Production; ://energycentral.com/c/ec/worldbattery-production Brian Wang

[5] BU-1003a: Battery Aging in an Electric Vehicle (EV); https://batteryuniversity.com/learn/article/bu_1003a_battery_aging_ in_an_electric_vehicle_ev, batteryuniversity.com

[6] Global Storage Market To Reach 305 GWh by 2030; Bloomberg New Energy Finance Predicts Energy Storage Market To Reach 125 GW/ 305 GWh By 2030

[7] Annual Europe residential storage deployment https://www.woodmac.com/reports/power-markets-global-energystorage-outlook-q3-2019-354911

[8] Are electric cars really that sustainable? - in Changeit; https://changeit.app/blog/2021-03-22-electrical-cars-howenvironmentally-friendly-are-they/

[9] Thalia VERKADE Why electric cars are always green (and how they could get greener) - https://thecorrespondent.com/7056/whyelectric-cars-are-always-green-and-how-they-could-getgreener/741917761200-afaa6e 5d

[10] Nissan says new 62-kWh-Leaf battery has AESC cells https://www.electrive.com/2019/01/10/nissan-continues-to-useaesc-cells-with-62-kwh-leaf/

[11] Andrea Varga - Peter Kadar: PhotoVoltaic EV Charge Station; 12th IEEE International Symposium on Applied Machine Intelligence and Informatics (SAMI 2013) Herlany, Slovakia Jan.31- Feb. 2., 2013 pp $1-4$

[12] Peter Kadar - Andrea Varga: Measurement of spectral sensitivity of PV cells; IEEE 10th International Symposium on Intelligent Systems and Informatics September 20-22, 2012; Subotica, Serbia

[13] Andrea Varga, Ervin Rácz, Péter Kádár: Experimental Determination of Maximum Power Points (MPPs) for Different Types of Photovoltaic Panels; SCIENTIFIC BULLETIN of the POLITEHNICA University of Timişoara, Romania, Transactions on AUTOMATIC CONTROL and COMPUTER SCIENCE, Vol. 58 (72), No. 2-4, June-December 2013 ISSN 1224-600X, pp 125-130.

[14] A. Vass - P. Kádár: Analysis of annual production of a multi-tilted PV system; SISY 2014: IEEE 12nd International Symposium on Intelligent Systems and Informatics; Subotica, Szerbia, 2014.09.1113.
[15] Peter Kadar: Behaviour of small scale dispersed PV generation; International Conference on Renewable Energies and Power Quality (ICREPQ'16); Madrid (Spain), 4-6th of May 2016 Renewable Energy and Power Quality Journal (RE\&PQJ) ISSN 2172-038 X, No.14 May 2016

[16] Varga Andrea, Rácz Ervin, Kádár Péter: Investigation of Photovoltaic Panel Losses using Computer Simulations; Elektroenergetika 2017, International Scientific Symposium, on Electrical Power Engineering, September

[17] Life Cycle Assessment https://www.sciencedirect.com/topics/earth-and-planetarysciences/life-cycle-assessment 